\title{
Protein Adsorption on Modified Bacterial Cellulose
}

\author{
Bambang Piluharto ${ }^{1,2, a}$, Fitri Sulistyowati ${ }^{2}$, Dwi Indarti ${ }^{1,2}$, Busroni $^{1,2}$, \\ D. Setiawan Purwo Handoko ${ }^{1,2}$ \\ ${ }^{1}$ Biomaterial Research Group, Universitas Jember, Jember 68121, East Java, Indonesia \\ ${ }^{2}$ Department of Chemistry, Faculty of Mathematics and Natural Sciences, Universitas Jember, \\ Jember 68121, East Java, Indonesia \\ abampito.fmipa@unej.ac.id
}

\begin{abstract}
The protein adsorption was interesting study, especially in the biological fluidic application. In the present study, we study the protein adsorption behavior on the bacterial cellulose and modified bacterial cellulose. In here, bacterial cellulose was modified by acid hydrolysis using hydrochloric acid. The contact time and $\mathrm{pH}$ were used as variable to study protein adsorption behavior on the modified bacterial cellulose. As the results, based on functional group analysis, there are not different between bacterial cellulose and modified bacterial cellulose. However, after modification, there was increasing of crystallinity of bacterial cellulose from $84.5 \%$ to be $87.7 \%$. In the protein adsorption study, increasing the contact time increase percent adsorption until contact time of 90 minutes, however the further contact time relatively constant. The protein adsorption on both of bacterial cellulose and modified bacterial cellulose decreases, following the increase of $\mathrm{pH}$.
\end{abstract}

Keywords: Bacterial Cellulose, Protein Adsorption, Acid Hydrolysis

\section{Introduction}

Bacterial Cellulose (BC) is cellulose that biosynthesized by certain bacteria, e.g, Rhizobium spp., Agrobacterium spp., Acetobacter spp., and Alcaligenes spp. Compare with cellulose from plants, BC have advantageous properties such as high purity, high crystallinity, and high tensile strength. As a result of its advantageous properties, BC have been widely used in various field applications such biomedical, food industry and paper industry [1-3].

Nanometric dimension of $\mathrm{BC}$ fibres lead to high surface area and potential to be adsorbent material. Using BC as adsorbent have been used for dyes, heavy metals and protein [3,4]. Protein adsorption is interested study, especially for biomedical applications. Various chemically modified of $\mathrm{BC}$ have been developed for protein adsorption, Phosphorylation Bacterial Cellulose (PBC), Querterner Ammonium Bacterial Cellulose (QABC), and Carboxymethyl Bacterial Cellulose (CBC) and acid hydrolysis-base were some modified of $B C$ for protein adsorption [5-8]. Acid hydrolysis is one of the modified cellulose that have many used to generate Cellulose Nano Crystal (CNC) with high crystallinity and high surface area [9].

The aim in this work is modied bacterial cellulose by acid hydrolysis and used it as adsorbent for protein adsorption. In here, hydrochloric acid was used as hydrolysis agent. Analysis structure, crystallinity and surface charge group were used to observed modified bacterial cellulose. Study adsorption was carried by batch method with various contact time and $\mathrm{pH}$. 


\section{Methods}

\section{Preparation of Bacterial Cellulose}

Bacterial Cellulose is produced from Nata de coco with a 10-day fermentation period. Nata de coco $10 \mathrm{~kg}$ is cut into $2 \times 2 \mathrm{~cm}$ small boxes to make boiling easier. Nata de coco is boiled with $2 \% \mathrm{NaOH}(\mathrm{w} / \mathrm{v})$ at $70{ }^{\circ} \mathrm{C}$ for 1 hour to remove acetic acid, urea, and residual fermented sugar [10]. Nata de coco is then washed with water repeatedly and the $\mathrm{pH}$ of the washing water is measured using $\mathrm{pH}$ meter to $\mathrm{pH} 7$ (neutral). Nata de coco is blended with maximum speed until it becomes porridge. Nata de coco porridge is filtered and dried in an oven at $95^{\circ} \mathrm{C}$ for 8 hours. The Nata de coco plate produced from the oven process is blended until smooth. Nata de coco powder is sieved with a 60 mesh sieve and the powder is taken through the sieve.

\section{Modification of Bacterial Cellulose}

$\mathrm{HCl} 6 \mathrm{M}$ of $480 \mathrm{~mL}$ is put into a round bottom flask and stirred with the stirrer to a temperature of $70{ }^{\circ} \mathrm{C}$. Then, 8.0009 grams of Bacterial Cellulose powder are added to a round bottom flask [11]. The mixture is stirred with the stirrer for 2 hours. The suspension is added with distilled water to a volume of $1000 \mathrm{~mL}$ to stop the reaction. The suspension is centrifuged at 10,000 rpm for 10 minutes. The $\mathrm{pH}$ of the supernatant after centrifugation was measured using a universal $\mathrm{pH}$ indicator to $\mathrm{pH} 7$ (neutral) [11]. Neutralizing Bacterial Cellulose was then 15 minutes ultrasounded with Ultrasonic Branson Sonifer-250 Power $250 \mathrm{~W}$, Electrical: $100 \mathrm{~V}, 50 / 60 \mathrm{~Hz}, 3$ A. Then centrifuged and the resulting pellet was dried in an oven at $50{ }^{\circ} \mathrm{C}$ for 30 minutes. The result is further refined with mortar and pestle [12].

\section{Conductometric Titration}

Bacterial Cellulose powder of 0.5000 grams modified are put into a $1000 \mathrm{~mL}$ three-neck flask, then $250 \mathrm{~mL}$ of $0.001 \mathrm{M}$. NaCl is added to the mixture and then added to $5 \mathrm{~mL}$ of $0.05 \mathrm{M} \mathrm{HCl}$ solution. The solution is stirred with the stirrer and its conductivity is measured with a conductometer that has been calibrated with $0.01 \mathrm{M} \mathrm{KCl}$ solution. The solution is added $\mathrm{NaOH}$ gradually with an initial volume of $0.5 \mathrm{~mL} 0.01 \mathrm{M} \mathrm{NaOH}$ to approach the turning point. When approaching the turning point of $0.1 \mathrm{M}$ as much as $0.1 \mathrm{M}$ in addition to know the exact initial volume when $\mathrm{HCl}$ runs out. The addition of $\mathrm{NaOH}$ is carried out gradually until the value of conductivity is constant. Measurement of conductivity at room temperature under nitrogen gas pressure [13].

The number of carboxyl charge groups (COO-) can be calculated from the titration curve using equation 1.

$$
\mathrm{COO}-(\mathrm{mmol} / \mathrm{kg})=\frac{C \times(V 2-V 1)}{m}
$$

Where, $\mathrm{C}$ is concentration of $\mathrm{NaOH}$ solution (mmol L-1), $\mathrm{m}$ is sample dry weight $(\mathrm{kg}), \mathrm{V} 1$ is the volume of $\mathrm{NaOH}$ is consumed at the first intersection point $(\mathrm{L})$ and $\mathrm{V} 2$ is the volume of $\mathrm{NaOH}$ is consumed at the second intersection point $(\mathrm{L})$ [13].

\section{Adsorption Test}

Adsorption experiment carried out by batch technique to examine effect of contact time and $\mathrm{pH}$. The other, batch technique also used to kinetic study. In here, bovine serum albumin (BSA) was selected as model protein in the present study. 


\section{Effect of Contact Time on BSA Adsorption}

BSA solution of $400 \mathrm{mg} / \mathrm{L}$ is added into a $100 \mathrm{~mL}$ Erlenmeyer. Then $0.1000 \mathrm{~g}$ of adsorbent was added [8]. The mixture is shaken with a shaker at a speed of $100 \mathrm{rpm}$ to avoid protein damage [14]. Shuffle is done with a time range of $60,90,120,150$ and 180 minutes. The suspension is filtered with filter paper. Filtrate was taken $50 \mu \mathrm{L}$ and put in a cuvette. The solution was added to $2.5 \mathrm{~mL}$ of Bradford reagent and allowed to stand for 5 minutes. The absorbance solution was measured by a visible spectrometer at maximum wavelength [15].

\section{Effect of pH on BSA Adsorption}

Protein solution of Bovine Serum Albumin (BSA) concentration of $400 \mathrm{mg} / \mathrm{L}$ was made by taking $20 \mathrm{~mL}$ of Bovine Serum Albumin (BSA) solution of $1000 \mathrm{mg} / \mathrm{L}$ and put it in a $50 \mathrm{~mL}$ volumetric

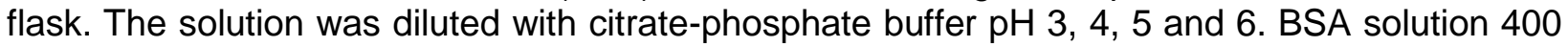
$\mathrm{mg} / \mathrm{L}$ from a $50 \mathrm{~mL}$ volumetric flask was then put into a $100 \mathrm{~mL}$ Erlenmeyer. Solution added $0.1000 \mathrm{~g}$ of adsorbent [8]. The mixture is shaken with a $100 \mathrm{rpm}$ speed shaker to avoid protein damage [14]. Shaking is done as long as the time that has been generated when there is equilibrium. The suspension is filtered with filter paper. Filtered filtrate was taken $50 \mu \mathrm{L}$ and put in a cuvette. The solution was added to $2.5 \mathrm{~mL}$ Bradford reagent and allowed to stand for 5 minutes. The absorbance solution was measured by a visible spectrometer at maximum wavelength [15].

\section{Results and Discussion}

Functional Group Analysis by FTIR

Figure 1 shows FTIR-spectra for both of $B C$ and MBC have similar bands, indicate that after acid hydrolysis treatment did not change structure on BC. Broad bands at 3346 represent to $\mathrm{O}-$ $\mathrm{H}$ stretching vibration, the band $2897 \mathrm{~cm}^{-1}$ to $\mathrm{C}-\mathrm{H}$ stretching vibration, $1431 \mathrm{~cm}^{-1}$ to $\mathrm{C}-\mathrm{H}$ bending vibration, and $1058 \mathrm{~cm}^{-1}$ to $\mathrm{C}-\mathrm{O}-\mathrm{C}$ bending vibration.

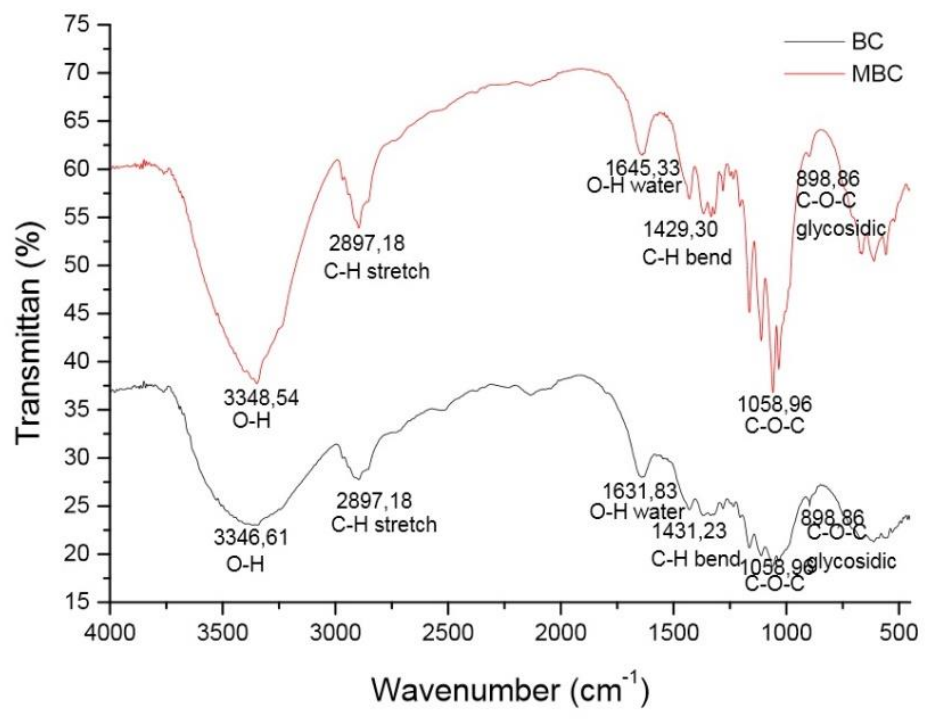

Figure 1. FTIR Spectra of BC and MBC 


\section{Crystallinity by XRD and Surface Charge Group}

XRD analysis was used to determine changes in the degree of crystallinity of $\mathrm{BC}$ after acid hydrolysis treatment. Figure 2 shows that there is increasing crystallinity from $84.5 \%(\mathrm{BC})$ to $87.7 \%$ (MBC). Increasing degrees of crystallinity due to remove amorphous region in the $\mathrm{BC}$ after acid hydrolysis treatment. During hydrolysis, hydrochloric acid breaks the 1.4 beta glycoside bond in the amorphous region [10]. Surface charge group of MBC was determined by conductometric titration. Charge group is sulfat group that attach on the BC structure. As the result, surface charge group of $\mathrm{MBC}$ is $9 \mathrm{mmol} / \mathrm{kg}$.

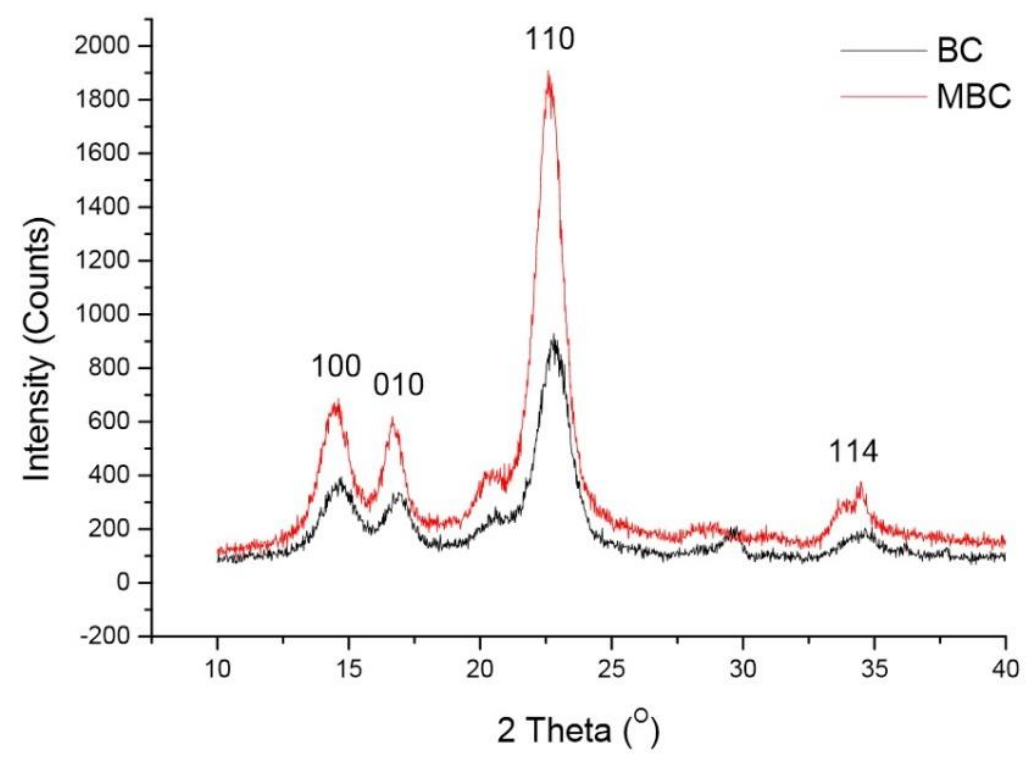

Figure 2. X-Ray Diffraction pattern of $\mathrm{BC}$ and $\mathrm{MBC}$

\section{Effect of Contact Time}

Figure 3 shows effect of contact time for protein adsorption show that adsorption equilibrium is reached within 90 minutes for both $\mathrm{BC}$ and $\mathrm{MBC}$, and further increase of contact time, it was not change significantly. Compare with $\mathrm{BC}, \mathrm{MBC}$ have higher protein adsorption capacity. It can be explained that after acid hydrolysis treatment, MBC have surface charge group that play important role in increasing adsorption capacity. 


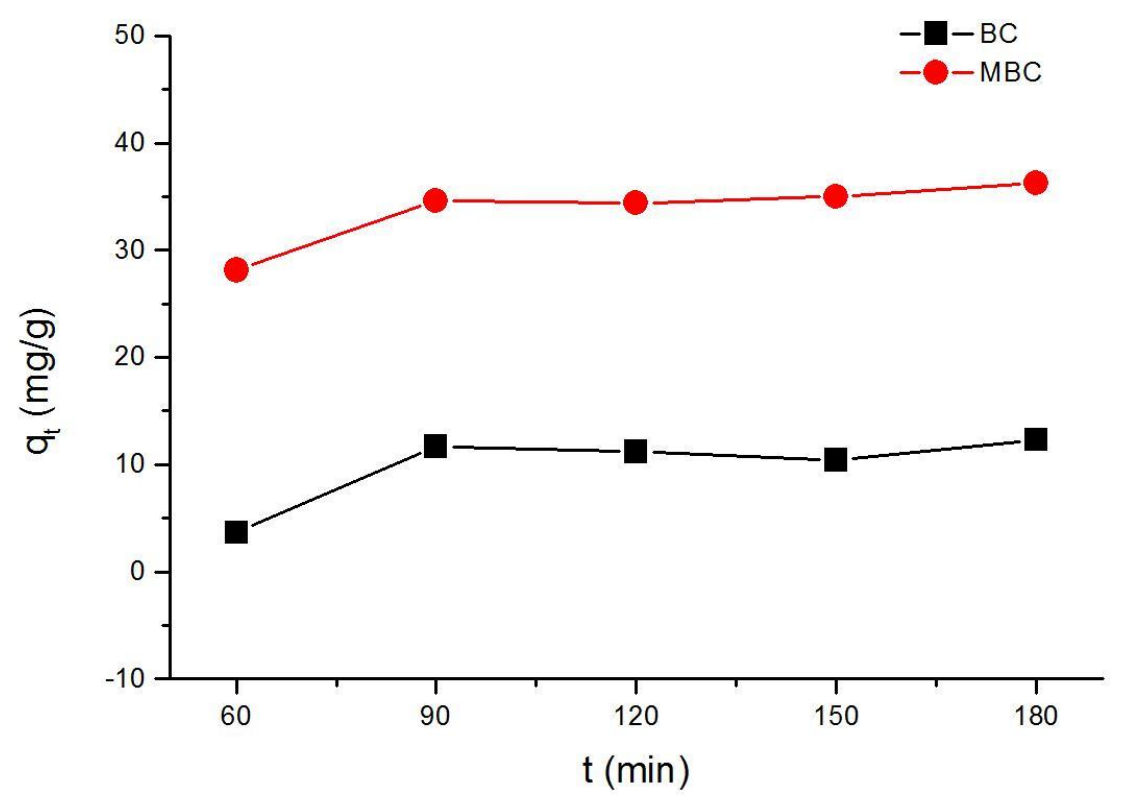

Figure 3. Effect of time on protein adsorption

\section{Effect of $\mathrm{pH}$}

Figure 4 shows that the protein adsorption capacity on both of $\mathrm{BC}$ and $\mathrm{BC}$ decreased with increasing $\mathrm{pH}$. Protein adsorption is highest in the $\mathrm{pH}$ of 3 . It can be explained that $\mathrm{pH}$ below the isoelectric point lead to positively charge of protein that generate high interaction with MBC that have negatively charge. In the other hand, $\mathrm{pH}$ above the isoelectric point lead to negatively charge of protein, consequently electrostatic repulsion take place [8]. 


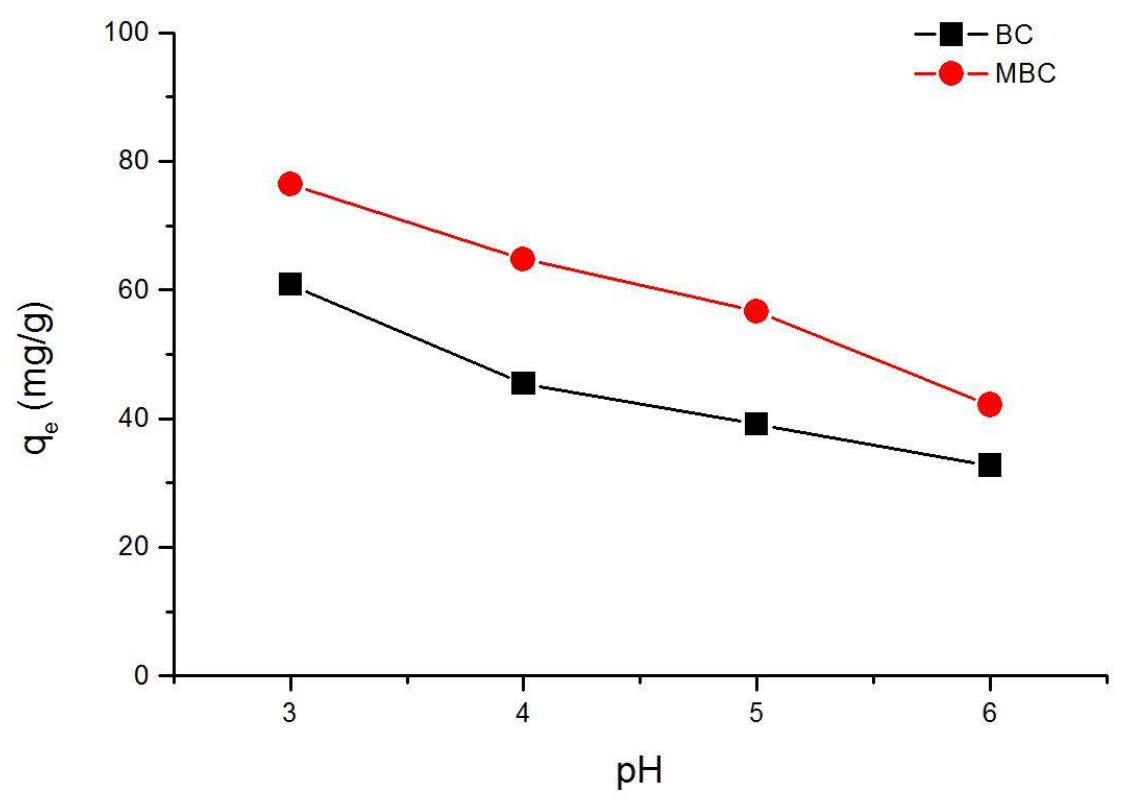

Figure 4. Effect of $\mathrm{pH}$ on protein adsorption

\section{Kinetic study}

In here, pseudo second order model was selected as kinetic study in this present study. pseudo second order model described binding capacity was proportional to the number of active sites occupied on the sorbent (Equation 2) [16].

$\frac{t}{q_{t}}=\frac{t}{q_{e}}+\frac{1}{q_{e}^{2} k}$

Where, $k$ is the equilibrium rate constant of pseudo second order adsorption kinetics [ $\mathrm{g} / \mathrm{mg} \mathrm{min}]$, $q_{e}$ the amount of metal ion adsorbed at equilibrium [mg/g], $q_{t}$ the amount of absorbate on the surface of sorbent at any time $t[\mathrm{mg} / \mathrm{g}]$ 


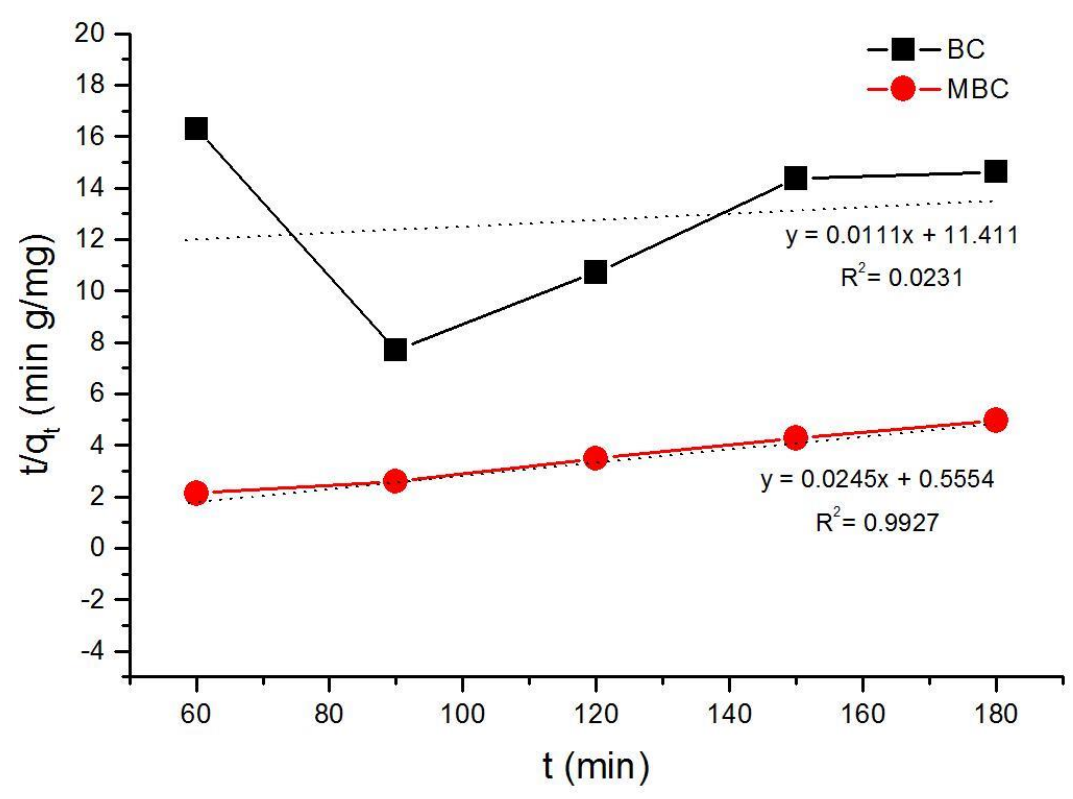

Figure 5. Pseudo second order model of protein adsorption on BC and MBC

Based on Figure 5, the pseudo second order model is suitable for MBC but not for BC. The result of the constant values obtained is 3.03 .

\section{Conclusions}

Modified Bacterial Cellulose ( $\mathrm{MBC}$ ) by acid hydrolysis has been successfully prepared as adsorbent for protein. Compare with Bacterial Cellulose (BC), BC have higher in adsorption capacity. Protein adsorption below the isoelectric point is higher for both of $\mathrm{BC}$ and $\mathrm{MBC}$. It is due to electrostatic interaction between adsorbent and adsorbat. Based on kinetic study using pseudo second order kinetic model, kinetic constant is 3.03 .

\section{ACKNOWLEDGEMENTS}

This research was supported by funding of Ministry of Research and Technology, Republic of Indonesia 2018.

\section{References}

[1] P. Gatenholm, and D. Klemm, 2010, Bacterial Nanocellulose as A Renewable Material for Biomedical Applications, Material Research Society Bulletin, volume 35, page 208-213.

[2] A.M.A. Gallegos, S.H. Carrera, R. Parra, T. Keshavarz, and H.M. lqbal, 2016, Bacterial Cellulose: A Sustainable Source to Develop Value-Added Products-A Review, BioResources, volume 11, no. 2, page 5641-5655. 
[3] C. Vilela, R.J. Pinto, A.R. Figueiredo, C.P. Neto, A.J. Silvestre, and C.S. Freire, 2017, Development and Applications of Cellulose Nanofibres Based Polymer Nanocomposites, Advanced Composite Materials: Properties and Applications. ed. E. Bafekrpour, page 1-65.

[4] Mohite, V. Bhavna, Patil and V. Satish, 2014, Bacterial Cellulose of Gluconoacetobacter hansenii as a Potential Bioadsorption Agent for Its Green Environment Applications, Journal of Biomaterials Science, Polymer Edition, volume 25, no.18, page 2053-2065.

[5] T. Oshima, S. Taguchi, K. Ohe, and Y. Baba, 2011, Phosphorylated Bacterial Cellulose for Adsorption of Proteins, Carbohydrate Polymers, volume 83, no. 2, page 953-958.

[6] T. Niide, H. Shiraki, T. Oshima, Y. Baba, N. Kamiya, and M. Goto, 2010, Quaternary Ammonium Bacterial Cellulose for Adsorption of Proteins, Solvent Extraction Research and Development, Japan, volume17, page 73-81.

[7] Q. Lin, Y. Zheng, G. Wang, X. Shi, T. Zhang, J. Yu, and J. Sun, 2015, Protein Adsorption Behaviors of Carboxymethylated Bacterial Cellulose Membranes, International Journal of Biological Macromolecules, volume 73, page 264-269.

[8] T.S. Anirudhan, S.R. Rejeena, \& A.R. Tharun, 2013, Investigation of The Extraction of Hemoglobin by Adsorption onto Nanocellulose-Based Superabsorbent Composite Having Carboxylate Functional Groups from Aqueous Solutions: Kinetic, Equilibrium, and Thermodynamic Profiles. Industrial \& Engineering Chemistry Research, volume 52, no. 32, page 11016-11028.

[9] C. Chirayil, J.L. Mathew, \& S. Thomas, 2014, Review of Recent Research in Nano Cellulose Preparation from Different Lignocellulosic Fibers. Reviews on Advanced Materials Science, volume 37.

[10] T. Mulyono, Asnawati, I. Noviandri, dan Buchari, 2007, Potensi Membran Nata De Coco sebagai Material Biosensor (The Use of Nata de Coco Membrane as Biosensor Material). Jurnal Ilmu Dasar, volume 8, no.2, page 128-134.

[11] Y. Yue, C. Zhou, A. D. French, G. Xia, G. Han, dan Q. Wang, dan Q. Wu, 2012, Comparative Properties of Cellulose Nano-Crystals from Native And Mercerized Cotton Fibers, Cellulose, volume 19, no. 4, page 1173-1187.

[12] M. Loelovich, 2012, Optimal Conditions for Isolation of Nanocrystalline Cellulose Particles. Nanoscience and Nanotechnology, volume 2, no. 2, page 9-13.

[13] A. Romdhane, M. Aurousseau, A. Guillet, dan E. Mauret, 2015, Effect of $\mathrm{pH}$ and lonic Strength on The Electrical Charge and Particle Size Distribution of Starch Nanocrystal Suspensions. Starch/Stärke, volume 67, issue 3-4, page 319-327.

[14] B.V. Mohite, dan S. V. Patil, 2014, Bacterial Cellulose of Gluconoacetobacter Hanseniia as a Potential Bioadsorption Agent For Its Green Environment Applications. Journal of Biomaterials Science Polymer Edition, volume 25, no.18, page 2053-2065. 
[15] M.M. Bradford, 1976, A Rapid and Sensitive Method for The Quantitation of Microgram Quantities of Protein Utilizing the Principle of Protein-Dye Binding, Analytical Biochemistry, volume 72 , issue $1-2$, page $248-254$.

[16] M. Stojanović, Z. Lopičić, J. Milojković, Č. Lačnjevac, M. Mihajlović, M., Petrović, \& A. Kostić, 2012, Biomass Waste Material as Potential Adsorbent for Sequestering Pollutants. Zaštita Materijala, volume 53, no. 3, page 231-237. 